\title{
Expression of Multidrug Resistance 1, Lung Resistance Protein and Breast Cancer Resistance Protein Genes in Chronic Leukemias
}

\author{
Ozlem D. ISERI ${ }^{1 *}$, Meltem D. KARS ${ }^{1}$, Pelin MUTLU ${ }^{1}$, Ferit AVCU ${ }^{2,3}$, Ali U. URAL ${ }^{2,3}$, Ufuk GUNDUZ ${ }^{1}$
}

\author{
${ }^{1}$ Middle East Technical University, Department of Biological Sciences \\ "Institute of Transplantation and Gene Sciences, Baskent University \\ ${ }^{2}$ Gulhane Military Medical Academy, Department of Hematology \\ ${ }^{3}$ Gulhane Military Medical Academy, Research Center, Ankara, TURKEY
}

\begin{abstract}
One of the major problems in treatment of leukemias is multidrug resistance, which is already present at diagnosis or develops after chemotherapy. The gene expression levels of multidrug resistance resistance 1 (MDR1), breast cancer resistance protein (BCRP) and lung resistance-resistance protein (LRP) were evaluated in blood samples of $20 \mathrm{CLL}$ and $24 \mathrm{CML}$ patients using RT-PCR. MDR1, BCRP and LRP expression levels were detected in 65\%, 20\% and 45\% of CLL patients, and in $54 \%, 37 \%$ and $25 \%$ of CML patients, respectively. $20 \%$ of CLL patients and $33 \%$ of CML patients expressed none of the genes. The other $20 \%$ of CLL patients expressed all the genes. $17 \%$ of CML patients expressed all of these genes, and two of them rapidly progressed to acute leukemia. MDR and LRP expressions seem to be frequent events in CLL and CML patients; however no conclusion can be drawn on their prognostic role and response to the treatment.
\end{abstract}

Keywords: CLL, CML, Multidrug resistance, MDR, LRP, BCRP

ÖZET

Kronik Lenfositik Lösemi ve Kronik Myelositer Lösemi Vakalarında Çoklu ilaç Direnç 1, Akciğer Direnç Protein ve Meme Kanseri Direnç Protein Genlerinin Tanımlanması

Lösemi tedavisinde en önemli problemlerden birisi hastada zaten var olan veya kemoterapi sırasında gelişen, kemoterapötik ilaçlara karşı ilaç direncinin gelişmesidir. Çoklu ilaç dirençliliği genleri olan MDR1, BCRP, LRP gen ifadeleri 20 KLL ve 24 KML hastasında GT-PZR metoduyla belirlenmiştir. Çoklu ilaç dirençliliği genleri olan MDR1, BCRP, LRP gen ifadeleri 20 KLL ve 24 KML hastasında GT-PZR metoduyla belirlenmiştir. MDR1, BCRP ve LRP gen ifade düzeyleri KLL vakalarının sırasıyla \%65, \%20 ve \%45'inde; KML vakalarının ise \%54, \%37 ve \%25'inde bulunmuştur. KLL vakalarııı \%20'sinde ve KML vakalarının \%33'ünde ise genlerin ifadeleri gözlenmemiştir. KLL hastalarının diğer \%20'si ise incelenen genleri ifade etmişlerdir. KML hastalarının \%17'si her üç geni ifade etmişler ve hastalardan ikisi akut lösemiye hızlı bir şekilde geçiş göstermişlerdir. MDR1 ve LRP gen ifadelerinin KLL ve KML için anlamlı olduğu anlaşılmaktadır. Ancak, gen ifadelerinin prognostik önemlerinin belirlenebilmesi açısından anlamlı bir sonuç çıkarılamamışır.

Anahtar Kelimeler: KLL, KML, Çoklu ilaç dirençliliği, MDR, LRP, BCRP 


\begin{tabular}{|c|c|c|c|c|c|c|}
\hline & \multicolumn{3}{|c|}{ CLL $n=20$} & \multicolumn{3}{|c|}{ CML $\quad n=24$} \\
\hline & MDR1 & BCRP & LRP & MDR1 & BCRP & LRP \\
\hline Patients (n) & 13 & 4 & 9 & 13 & 9 & 6 \\
\hline MDR1 association & - & $p=0.249$ & $p=0.63$ & - & $p=0.423$ & $p=0.016$ \\
\hline BCRP association & $p=0.249$ & - & $p=0.285$ & $p=0.423$ & - & $p=0.15$ \\
\hline LRP association & $p=0.630$ & $p=0.285$ & - & $p=0.016$ & $p=0.15$ & - \\
\hline $\begin{array}{l}\text { Patients with initial } \\
\text { diagnosis }(n)\end{array}$ & $\begin{array}{l}12 \\
(p=0.031)\end{array}$ & $\begin{array}{l}3 \\
(p=0.751)\end{array}$ & $\begin{array}{l}5 \\
(p=0.127)\end{array}$ & $\begin{array}{l}2 \\
(p=0.357)\end{array}$ & $\begin{array}{l}3 \\
(p=0.635)\end{array}$ & $\begin{array}{l}1 \\
(p=1.0)\end{array}$ \\
\hline $\begin{array}{l}\text { Patients having imatinib } \\
\text { treatment }(n)\end{array}$ & - & - & - & $\begin{array}{l}10 \\
(p=0.038)\end{array}$ & $\begin{array}{l}5 \\
(p=0.625)\end{array}$ & $\begin{array}{l}4 \\
p=0.649\end{array}$ \\
\hline $\begin{array}{l}\text { Time from diagnosis } \\
\text { (years; median) }\end{array}$ & $\begin{array}{l}3 \\
(p=0.014)\end{array}$ & $\begin{array}{l}2 \\
(p=0.085)\end{array}$ & $\begin{array}{l}5 \\
(p=0.355)\end{array}$ & $\begin{array}{l}2 \\
(p=0.514)\end{array}$ & $\begin{array}{l}2 \\
(p=0.807)\end{array}$ & $\begin{array}{l}5 \\
(p=0.117)\end{array}$ \\
\hline
\end{tabular}

ficant association was found between the treatment and the expression of the other resistance related genes (BCRP, LRP). According to Mann-Whitney test for continuous variables, the median of disease age for patients with observed MDR1 expression was significantly lower than the median of disease age for patients with no MDR1 expression ( $\mathrm{p}=$ 0.014). However the distribution of age was not significantly different in patients with or without MDR1 expression. The distribution of neither age nor disease age was significantly different for patients with or without BCRP and LRP gene expressions. According to Fisher's exact test for gene expression associations, there was no significant association among three genes analyzed.

\section{Resistance related gene expression of CML patients}

The ages of the patients were between 24 and 71 with a median of 41 years, and the time from diagnosis up to RNA isolation varied between less than 1 to 12 years with a median of 2 years (Table 1 ). Eighteen of 24 patients had chemotherapy at the time of blood sampling. Details of chemotherapy given to patients are listed in Table 1. The RT-PCR results indicate that 13 patients $(54.2 \%)$ expressed MDR1 gene. 9 patients (37.5\%) expressed BCRP and 6 patients (25\%) expressed LRP genes. Among patients having MDR1 gene expression, 5 patients had only MDR1 expression. In addition, 3 patients having BCRP expression had only BCRP expression. However all of the LRP expressing patients had also expression of MDR1 gene. 8 patients (33.3\%) expressed none of the resistance related genes. 4 patients $(16.7 \%)$ expressed all three genes analyzed. Densitometric measurements (Table 2), normalized to $32-\mathrm{m}$ expression, reveal that expression levels of these genes are different and variable in patients. MDR1/ß2-m densitometric ratio levels varied between 0.65-1.44 (median: 0.80) in MDR1 expressing patients. BCRP/B2-m densitometric ratio levels were in between 0.47-1.03 (median: 0.89) and LRP/B2-m levels were in between 0.65-0.98 (median: 0.79) in BCRP and LRP expressing patients, respectively.

\section{Statistical analysis for gene expression profiles of CML patients}

According to Fisher's exact test for binary variables, proportion of patients with MDR1 expression was significantly higher in patients who had imatinib treatment than in patients who did not have imatinib treatment $(\mathrm{p}=0.038)$ (Table 3). However no significant association was found between imatinib treatment and expression of BCRP and LRP genes. The distribution of neither age nor disease 


\section{INTRODUCTION}

Most patients with chronic leukemia typically respond to initial chemotherapy, but many have disease reoccurrence. One of the causes of disease is drug resistance that cancer cells acquire during chemotherapy. ${ }^{1}$ Multidrug resistance (MDR) describes a complex phenotype whose predominant feature is resistance to wide range of structurally unrelated anticancer agents and is a serious limitation to the effective chemotherapeutic treatment. ${ }^{2}$ There are several mechanisms by which cancer cells develop resistance to cytotoxic agents. One of the mechanisms is transport of drugs by transporter proteins, such as $\mathrm{P}$-glycoprotein (P-gp) or multidrug resistance protein $1(\mathrm{MDR} 1)^{3}$, and some of the others are breast cancer resistance protein (BCRP) ${ }^{4}$ and lung resistance-related protein (LRP; major vault protein). ${ }^{5}$

P-gp, a member of ATP-binding casette (ABC) transporter superfamily (ABCB1), is a $170-\mathrm{kD}$ transmembrane glycoprotein. It is capable of extruding a wide variety of large heterocyclic compounds, including antracyclines, vinca alkaloids and epipodophyllotoxins that are in use for treatment of hematologic malignancies. ${ }^{6}$ Normal tissues that express P-gp include epithelial cells of the gastrointestinal tract, adrenal gland, biliary canaliculi, and certain hematopoietic cells. ${ }^{7}$ It was previously reported that P-gp and the MDRl mRNA are expressed in normal leukocytes, however this expression is lineage specific with relatively high levels among CD56 ${ }^{+}$cells. ${ }^{8}$ In another study it was concluded that P-gp was expressed in $40 \%$ to $65 \%$ of healthy individuals specifically on $\mathrm{CD}^{5} 6^{+}$and $\mathrm{CD} 8^{+}$cells with variable quantitative expression. ${ }^{9}$

Most of anticancer agents are recognized not only by P-gp but also by other efflux transporters, including BCRP and LRP. ${ }^{10,11} \mathrm{BCRP}$ is a half $\mathrm{ABC}$ transporter and a member of the ABCG subfamily (ABCG2). ${ }^{12}$ Overexpression of BCRP results in cross-resistance to mitoxantrone, daunorubicin and topotecan, but not microtubular inhibitors such as paclitaxel and vinblastine. ${ }^{4}$ Tissues that express BCRP include epithelial cells of the digestive tract, biliary ducts and the mammary gland. It was also demonstrated that the BCRP is preferentially expressed and functionally active in human normal plasma cells..$^{13}$
LRP is a major nuclear vault protein with a barrelshaped structure. It forms central plugs of the nuclear pore complexes and functions to block the transport of drugs from the cytoplasm to the nucleus. ${ }^{5}$ The overexpression of LRP was identified by Scheper et al..$^{14}$ in a lung cancer line. The spectrum of cross-resistance of LRP is wide, covering the classical MDR phenotype as well as the planitoland melphalan-resistant phenotypes. ${ }^{15}$ LRP overexpression has also been observed in blast cells of acute myeloid leukemia (AML) and seemed to be increased in patients who respond poorly to anthracycline..$^{16,17}$

There is significant individual variation in the expression and/or function of $\mathrm{ABC}$ transporters, which will lead to widely variable bioavailability of the drugs. The expression and function of efflux transporters are variable depending on a variety of influencing factors such as co-administered drugs, daily food and drink, disease progression and so on. ${ }^{18}$

The aim of the present study was to evaluate MDR1, BCRP and LRP gene expression by reverse transcription-polymerase chain reaction (RTPCR) in 20 adult chronic lymphocytic leukemia (CLL) and 24 adult chronic myelogeneous leukemia (CML) patients as predictors of both prognosis and response to chemotherapy.

\section{PATIENTS AND METHODS}

\section{Patients}

Peripheral blood samples collected from patients diagnosed as CLL and CML were used in this study after approved from the ethics committee of Gulhane Military Medical Academy. All subjects gave informed consent for participating in the study. Patient characteristics are given in Table 1.

\section{RNA isolation and Reverse Transcription-Poly- merase Chain Reaction (RT-PCR)}

RNA of 20 CLL and 24 CML patients were isolated from blood samples of patients. Isolation of white blood cells (WBCs) from blood samples was performed by ficoll separation method for RNA isolation. ${ }^{19}$ RNA isolations from WBCs of the patients were performed by guanidium thiocyanide/phenol-chloroform single step RNA isolation 


\begin{tabular}{|c|c|c|c|c|c|c|c|}
\hline \multicolumn{2}{|c|}{ CLL patients MDR1/b2m } & \multirow{2}{*}{$\begin{array}{l}\text { BCRP/b2m } \\
N D\end{array}$} & \multirow{2}{*}{$\begin{array}{l}\text { LRP/b2m } \\
0.85\end{array}$} & \multirow{2}{*}{$\begin{array}{l}\text { CML patients } \\
1\end{array}$} & \multirow{2}{*}{$\begin{array}{l}\text { MDR1/b2m } \\
\text { ND }\end{array}$} & \multirow{2}{*}{$\begin{array}{l}\text { BCRP/b2m } \\
\text { ND }\end{array}$} & \multirow{2}{*}{$\begin{array}{l}\text { LRP/b2m } \\
\text { ND }\end{array}$} \\
\hline 1 & $N D^{*}$ & & & & & & \\
\hline 2 & ND & ND & 0.67 & 2 & ND & ND & ND \\
\hline 3 & 1.41 & ND & ND & 3 & ND & ND & ND \\
\hline 4 & ND & ND & ND & 4 & ND & ND & ND \\
\hline 5 & ND & ND & ND & 5 & ND & ND & ND \\
\hline 6 & 0.99 & ND & ND & 6 & 0.89 & ND & 0.79 \\
\hline 7 & ND & ND & 0.57 & 7 & 0.80 & 0.88 & 0.00 \\
\hline 8 & 1.02 & ND & 1.23 & 8 & ND & ND & ND \\
\hline 9 & 0.77 & 0.81 & ND & 9 & 0.80 & 0.89 & 0.71 \\
\hline 10 & ND & ND & ND & 10 & ND & ND & ND \\
\hline 11 & 1.16 & ND & ND & 11 & 0.91 & 0.93 & 0.78 \\
\hline 12 & 0.93 & 0.82 & 0.59 & 12 & 1.03 & 0.90 & 0.98 \\
\hline 13 & ND & ND & ND & 13 & 1.03 & ND & ND \\
\hline 14 & 0.89 & 0.80 & 1.15 & 14 & 0.75 & ND & 0.83 \\
\hline 15 & 0.74 & ND & 0.80 & 15 & 0.73 & 0.73 & ND \\
\hline 16 & 0.71 & ND & 0.53 & 16 & ND & 1.03 & ND \\
\hline 17 & 0.69 & 0.76 & 0.60 & 17 & ND & 0.92 & ND \\
\hline 18 & 1.10 & ND & ND & 18 & ND & 0.74 & ND \\
\hline 19 & 0.68 & ND & ND & 19 & 0.68 & 0.47 & 0.65 \\
\hline \multirow[t]{5}{*}{20} & 0.87 & ND & ND & 20 & 0.65 & ND & ND \\
\hline & & & & 21 & ND & ND & ND \\
\hline & & & & 22 & 0.73 & ND & ND \\
\hline & & & & 23 & 1.27 & ND & ND \\
\hline & & & & 24 & 1.44 & ND & ND \\
\hline
\end{tabular}

\section{RESULTS}

\section{Resistance related gene expression of CLL patients}

The ages of patients were between 43 and 79, and the time from diagnosis up to RNA isolation varied between 1 to 14 years with a median of 3 years (Table 1). Only five patients had taken fludarabine therapy, previously. The RT-PCR results indicate that 13 patients out of $20(65 \%)$ expressed MDR1 gene. Four patients (20\%) expressed BCRP and 9 patients (45\%) expressed LRP genes. Among 13 patients having MDR1 gene expression, 6 patients had only MDR1 expression. In addition, among 9 patients having LRP gene expression, 3 patients had only LRP expression. However, all of the BCRP expressing patients had also expression of MDR1 and LRP genes. Four patients (20\%) were not expressed any resistance related genes. Only 3 patients $(15 \%)$ expressed all three genes. Densitometric measurements (Table 2) revealed that expression levels of these genes were different and variable in patients. MDR1/ß2-m densitometric ratio levels varied between 0.68-1.41 (median: 0.89) in MDR1 expressing patients. BCRP/B2-m densitometric ratio levels were in between 0.76-0.82 (median: 0.81) and LRP/B2-m levels were in between 0.53-1.23 (median: 0.67) in BCRP and LRP expressing patients, respectively.

\section{Statistical analysis for gene expression profiles of CLL patients}

According to Fisher's exact test for binary variables, proportion of patients with MDR1 gene expression was significantly higher in patients who didn't have treatment than in patients who had treatment previously $(\mathrm{p}=0.031)$ (Table 3$)$. However, no signi- 
Table 1. Characteristics of CLL and CML patients.

\begin{tabular}{|c|c|c|}
\hline Characteristics & CLL $n=20$ & CML $n=24$ \\
\hline Age (years) [Median (Range)] & $63(43-79)$ & $41(21-74)$ \\
\hline Gender (Male/Female) & $17 / 3$ & $18 / 6$ \\
\hline WBC (109/L) (Mean \pm SD) & $82.4 \pm 32.1$ & $46.0 \pm 37.2$ \\
\hline Chemotherapy (Yes/No) & $5 / 15$ & $18 / 6$ \\
\hline $\operatorname{Drug}^{*}(\mathrm{~F}){ }^{* *}(\mathrm{I} / \mathrm{FN} / \mathrm{H} / \mathrm{ID})$ & 5 & $14 / 1 / 3 / 6$ \\
\hline Time from diagnosis (years) [Median (Range)] & $3(<1-14)$ & $2(<1-12)$ \\
\hline Binet stage (A/B/C) & $5 / 11 / 4$ & - \\
\hline Disease status (Progression) ${ }^{\star \star \star}(\mathrm{S} / \mathrm{I} / \mathrm{F} / \mathrm{T})$ & $6 / 6 / 3 / 5$ & - \\
\hline \multicolumn{3}{|c|}{ 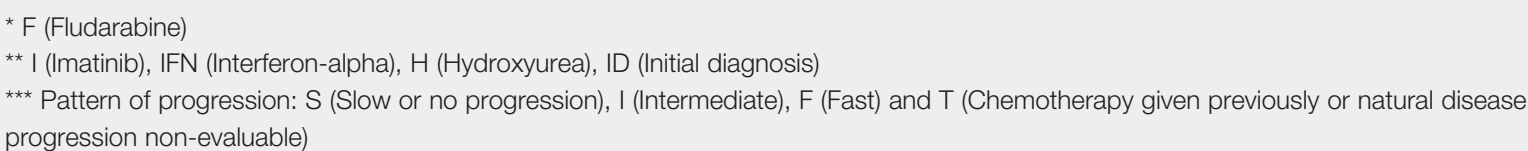 } \\
\hline
\end{tabular}

method. ${ }^{20}$ Absorbance values $(260 \mathrm{~nm}, 280 \mathrm{~nm})$ were measured for RNA quantification. RNA intactness was checked by agarose $(1 \% \mathrm{w} / \mathrm{v})$ gel electrophoresis (70V, $90 \mathrm{~min}$ ). cDNA synthesis (reverse transcription) was performed with $5 \mu \mathrm{g}$ of total RNA, $0.5 \mu \mathrm{g}$ oligo dT or 1 pmole gene specific primer and 70 units M-MuLV Reverse Transcriptase for each sample $\left(42^{\circ} \mathrm{C}, 1\right.$ hour $)$, according to manufacturer's instructions (MBI Fermentas, Lithuania). cDNA was used as template for PCR reaction, 1 unit Taq DNA polymerase (MBI Fermentas) was used for $50 \mu \mathrm{L}$ of reaction volume. MDR1, BCRP and LRP specific primers were used for the expression analysis. Beta-2 microglobulin (B2-m) level was used as the internal standard to normalize the expression levels of genes. MDR1 and B2-m primers were carefully selected from different exons of the genes to prevent amplification of contaminating DNA as previously described. ${ }^{21}$ BCRP and LRP specific primers and PCR conditions were previously described by Palissot et al. and Schaich et al., respectively. ${ }^{22,23}$ PCR conditions were as follows; initial denaturation at $94^{\circ} \mathrm{C}$ for $5 \mathrm{~min}$, denaturation at $94^{\circ} \mathrm{C}$ for $30 \mathrm{~s}$ (MDR1, LRP and $\beta 2-\mathrm{m}$ ) and for $50 \mathrm{~s}$ (BCRP), annealing at $55^{\circ} \mathrm{C}$ for $30 \mathrm{~s}(\beta 2-\mathrm{m})$, $56^{\circ} \mathrm{C}$ for $25 \mathrm{~s}$ (MDR 1 ), $59^{\circ} \mathrm{C}$ for $45 \mathrm{~s}$ (LRP) and for $50 \mathrm{~s}$ (BCRP), extension at $72^{\circ} \mathrm{C}$ for $30 \mathrm{~s}$ ( $(32-\mathrm{m})$, for
$25 \mathrm{~s}$ (MDR1), for $1 \mathrm{~min}$ (LRP) and for $20 \mathrm{~s}$ (BCRP), and final extension at $72^{\circ} \mathrm{C}$ for $10 \mathrm{~min}$. PCR cycles were set as 30 cycles for MDR1, LRP and $32-\mathrm{m}$ primers and 34 cycles for BCRP primers. PCR products were examined by native agarose $(2 \% \mathrm{w} / \mathrm{v})$ gel electrophoresis ( $90 \mathrm{~V}, 60 \mathrm{~min})$ and visualized with ethidium bromide staining. Densitometric measurements of band intensities were performed using Scion Image Software (Scion Corporation, USA). Amplicon sizes are 295, 356, 482 and 122 bp for MDR1, BCRP, LRP and B2-m, respectively.

\section{Statistical Analysis}

Analyses were carried out with the Statistical Package for the Social Sciences (SPSS) software, version 10.0 (SPSS Inc., Chicago, Illinois, USA) and the significance level was $5 \%(\mathrm{p}<0.05)$. Comparisons were performed using Fisher's exact test for binary variables (treatment versus existence of drug resistance gene expressions), and Mann-Whitney test for continuous variables (age of patient and disease versus existence of drug resistance gene expressions). Fisher's exact test was also used to investigate the association among resistance related gene expressions. 
age was significantly different for patients those who had or did not have expression of MDR1, BCRP and LRP genes. There was a significant association between expression of MDR1 with LRP gene $(p=0.016)$ in patients analyzed. However, there was neither significant association between expression of MDR1 with BCRP gene nor expression of LRP gene with BCRP gene.

\section{DISCUSSION}

A major obstacle to successful treatment of chronic leukemia is thought to be drug resistance, which is a determinant of the response to chemotherapy and radiotherapy and its detection may be of clinical importance. ${ }^{24,25}$ The situation regarding the resistance to treatment presented by some forms of hematological malignancies such as chronic leukemia is still controversial. During the last decade, it is revealed that functional expression of the resistance proteins P-gp, MRP, LRP or BCRP associated with the development of relapse and/or refractory disease. . $^{25}, 26$

P-glycoprotein (P-gp), encoded by the MDR1 gene, is an $\mathrm{ABC}$ transporter normally involved in the excretion of toxins from cells..$^{27.28}$ It was noted that this ATP-dependent drug efflux pump was part of a family of transporter genes, called ATP-binding cassette $(\mathrm{ABC})$ transporters. It is also overexpressed at baseline in chemotherapy-resistant tumors and upregulated after disease progression following chemotherapy in malignancies. ${ }^{29}$ The most reproducible studies on expression in human cancers involve leukemic cells. ${ }^{30,31}$ To date, the literature has reported several data about MRP1 expression of CLL patients, and its expression rate was very variable. In one study 54/68 (79\%) of CLL patients were found to have high levels of MDR1 gene expression. ${ }^{32}$ However, in another study 23/10 (37\%) of CLL patients were found to have lower levels of MDR1 expression, and MDR1 was expressed independently of exposure to precytotoxic agents. ${ }^{33}$ According to our RT-PCR results, MDR1 gene expression was observed in $65 \%$ of patients. MDR1 expression is usually dependent to the exposure to cytotoxic agents, however, the proportion of MDR1 expression was higher in our CLL patients who did not have any treatment than in patients who had fludarabine treatment. Although this seems controversi- al, considering only $25 \%$ of the patients had treatment where $75 \%$ did not, these results seems to be tentative on the effect of drug treatment in resistance related gene expressions in this sampling. The medians of disease age for patients with or without MDR1 expression were significantly different; the median of disease age for patients with observed MDR1 expression was significantly lower than median of patients without MDR1 expression. In addition fludarabine is not among the substrates of P$\mathrm{gp}^{34}$ and de novo expression due to treatment was unlikely.

So far, the differential impact of resistance gene expression on treatment outcome in CML is not well defined and the mechanisms of resistance and progression are poorly understood. In a study, MDR1 expression was found in 73 of 127 early chronic phase (57\%), 20 of 31 late chronic phase (65\%) in CML patients. However, the authors also reported that disease progression, response to interferon alpha and survival were independent from MDR1 expression. ${ }^{35}$ Our results are in agreement with this study and MDR1 gene expression of the patients was observed in 54.2\%.The drug imatinib has become a first-line therapy of CML for 6-7 years, however, the resistance to imatinib has been described in many patients. Drug efflux by Pglycoprotein (P-gp), as well as point mutations in $\mathrm{BCR} / \mathrm{ABL}$ oncoprotein, may be responsible for the mechanism of resistance to imatinib in $\mathrm{CML}^{36,37} \mathrm{In}$ addition alterations in ceramide metabolism were found to be involved in imatinib resistance in resistant K562 cells. ${ }^{38}$ In this study, $75 \%$ of CML patients had been treated with either hydroxyurea or imatinib previously. Here a significant association between MDR1 gene expression and imatinib treatment were found, and the proportion of MDR1 expression was significantly higher in patients who had imatinib treatment than in patients who did not have imatinib treatment. Interestingly, the expression of MDR1 and LRP genes was found to be associated in CML patients. MDR1 gene expression is more frequent in CML patients when compared to other resistance related genes, BCRP and LRP. These results must be elucidated with further studies.

LRP is the human major vault protein ${ }^{39}$ is frequently overexpressed in drug resistant cancer cells 
5. Scheffer GL, Schroeijers AB, Izquierdo MA, et al. Lung resistance-related protein/ major vault protein and vaults in multidrug-resistant cancer. Curr Opin Oncol 12: 550-556, 2000.

6. Cole SP, Bhardwaj G, Gerlach JH, et al. Overexpression of a transporter gene in a multidrug-resistant human lung cancer cell line. Science 258: 1650-1654, 1992.

7. Thiebaut F, Tsuruo T, Hamada Willingham MC. Immunohistochemical localization in normal tissues of different epitopes in a multidrug transport protein P170: Evidence for localization in brain capillaries and crossreactivity of one antibody with a muscle protein. J Histochem Cytochem 37: 159, 1989.

8. Klimecki WT, Futscher BW, Grogan TM, Dalton WS. P-Glycoprotein Expression and Function in Circulating Blood Cells From Normal Volunteers. Blood 83: 24512458, 1994.

9. Chaudhary PM, Mechetner EB, Roninson IB. Expression and Activity of the Multidrug Resistance PGlycoprotein in Human Periphera1 Blood Lymphocytes. Blood 80: 2735-2739, 1992.

10. Chan LMS, Lowers S, Hirst BH. The ABCs of drug transport in intestine and liver: efflux proteins limiting drug absorption and bioavailability. Eur J Pharm Sci 21: 25-51, 2004.

11. Burger H, Foekens JA, Look MP, et al. RNA expression of breast cancer resistance protein, lung resistance-related protein, multidrug resistance-associated proteins 1 and 2, and multidrug resistance gene 1 in breast cancer: correlation with chemotherapeutic response. Clin Cancer Res 9: 827-836, 2003.

12. Doyle LA, Ross DD. Multidrug resistance mediated by the breast cancer resistance protein BCRP (ABCG2). Oncogene 22: 7340-7358, 2003.

13. Raaijmakersa M, de Grouwb E, Heuverb L, et al. Impaired breast cancer resistance protein mediated drug transport in plasma cells in multiple myeloma. Leuk Res 29: 1455-1458, 2005.

14. Scheper RJ, Broxterman HJ, Scheffer GL, et al. Overexpression of a Mr-110,000 vesicular protein in nonPglycoprotein-mediated multidrug resistance. Cancer Res 53: 1475-1479, 1993.

15. Kitazono M, Sumizawa T, Takebayashi $Y$, et al. Multidrug resistance and the drug resistance related protein in human colon carcinoma SW-620 cells. J Natl Cancer Inst 91: 1647-1653, 1999.

16. Legrand $O$, Simonin G, Zittoun R, Maria JP. Comparison of MDR1, MRP and LRP expression with in vitro drug sensitivity and in vivo response to treatment in fresh blast cells from adult acute myeloid leukemia patients. Blood 90 (Suppl 1): 797, 1997.

17. Michieli M, Damiani D, Ermacora A, et al. P-glycoprotein (pgp) and lung resistance-related protein (LRP) expression and function in leukemic blast cells. $\mathrm{Br} J$ Haematol 96: 356-365, 1997.

18. Takano M, Yumoto R, Murakami T. Expression and function of efflux drug transporters in the intestine. Pharmacol Therapeut 109: 137-161, 2006.
19. Bignold LP. Preparative techniques influencing sedimentation of erythrocytes through the Hypaque-Ficoll medium used in the one-step technique for separation of human polymorphonuclear leukocytes from whole blood. J Immunol Methods 106: 147-149, 1988.

20. Chomczynski PS. Single step method of RNA isolation by acid guanidium thiocyanate-phenol-chloroform extraction. Analytical Biochem 162: 156-159, 1987.

21. Kars MD, Iseri OD, Gunduz $U$, et al. Development of rational in vitro models for drug resistance in breast cancer and modulation of MDR by selected compounds. Anticancer Res 26: 4559-4568, 2006.

22. Schaich M, Soucek S, Thiede C, et al. MDR1 and MRP1 gene expression are independent predictors for treatment outcome in adult acute myeloid leukaemia. Br J Haematol 128: 324-332, 2005.

23. Palissot $\mathrm{V}$, Morjani $\mathrm{H}$, Belloc F, et al. From molecular characteristics to cellular events in apoptosis-resistant HL-60 cells. Int J Oncol 26: 825-834, 2005.

24. Nørgaard JM, Hokland P. Biology of multiple drug resistance in acute leukemia. Int J Hematol 73: 132, 2001.

25. Hirose M, Hosoi E, Hamano S, Jalili A. Multidrug resistance in hematological malignancy. J Med Invest 50: 126-135, 2003.

26. Nørgaard JM, Olesen LH, Hokland P. Changing picture of cellular drug resistance in human leukemia. Crit Rev Oncol Hematol 50: 39-49, 2004.

27. Ueda K, Cornwell MM, Gottesman MM, et al. The mdr1 gene, responsible for multidrug-resistance, codes for P-glycoprotein. Biochem Biophys Res Commun 141: 956-962, 1986.

28. Ueda K, Clark DP, Chen CJ, et al. The human multidrug resistance (mdr1) gene. cDNA cloning and transcription initiation. J Biol Chem 262: 505-508, 1987.

29. Leonard GD, Fojo T, Bates SE. The role of ABC transporters in clinical practice. Oncologist 8: 411-424, 2003.

30. Yasunami T, Wang YH, Tsuji K, et al. Multidrug resistance protein expression of adult T-cell leukemia/lymphoma. Leuk Res 31: 465-470, 2007.

31. Han K, Kahng J, Kim M, et al. Expression of functional markers in acute nonlymphoblastic leukemia. Acta Haematol 104: 174-180, 2000.

32. Webb M, Brun M, McNiven M, et al. MDR1 and MRP expression in chronic B-cell lymphoproliferative disorders. Br J Haematol 102: 710-7, 1998.

33. Arai $Y$, Masuda M, Sugawara I, et al. Expression of the MDR1 and MDR3 gene products in acute and chronic leukemias. Leuk Res 21: 313-319, 1997.

34. Higashi $Y$, Turzanski J, Pallis M, Russell NH. Contrasting in vitro effects for the combination of fludarabine, cytosine arabinoside (Ara-C) and granulocycte colonystimulating factor (FLAG) compared with daunorubicin and Ara-C in P-glycoprotein-positive and P-glycoprotein-negative acute myeloblastic leukemia. $\mathrm{Br} \mathrm{J} \mathrm{Ha}$ ematol 111: 565-569, 2000. 
and its expression has been correlated with poor prognosis.$^{39,40}$ Vault proteins are present in all eukaryotic cells, and they are highly conserved ${ }^{41}$ Several clinical data have indicated that LRP expression can be of high clinical value to predict the response to chemotherapy in some tumor types such as non-small cell lung carcinoma, osteosarcoma, melanoma and neuroblastoma. ${ }^{42-46}$ The biological and clinical significance of LRP in CLL is still unclear. To our knowledge, the expression of LRP in CLL has been reported in only one study. Consoli et al. ${ }^{47}$ stated that no differences were observed in CLL patients when patients were grouped as untreated and treated with at least one line of treatment. However, significantly higher levels of LRP protein were measured in MRP-positive than in MRP-negative patients. According to our results, LRP gene expression was observed in $45 \%$ of CLL patients. MDR1 and LRP gene expressions were more frequent among CLL patients when compared with BCRP expression. In addition no significant correlation was found between drug treatment and expressions of LRP and BCRP genes.

Carter et al. ${ }^{48}$ revealed that the expression levels of LRP in CML patients were similar to those observed in healthy individuals. Thus, as the resistance observed in healthy donors was limited to a small number of individuals, LRP gene does not seem to mediate the resistance observed in CML patients. LRP gene expression was observed in $25 \%$ of our CML patients. Also, the proportion of LRP expression was lower than proportion of patients that did not express any of the resistance related genes (33.3\%). The data suggest that LRP expression is not one of the mechanisms of drug resistance in CML; however, we have not yet had the opportunity to measure serially the expression levels of LRP in patients. Such a prospective analysis would be of considerable interest.

Little is known about BCRP gene expression in acute and chronic leukemia. Only one study revealed that $4 / 7(57 \%)$ overexpression of BCRP in CLL patients ${ }^{49}$ However, the proportion of patients with BCRP expression was same with the proportion of patients that did not express any of the resistance related genes (20\%). BCRP gene expression was more frequent among CLL patients when compared with MDR1 and LRP expression. No signifi- cant correlation was found between drug treatment and expressions of BCRP genes.

BCRP may play a role in drug resistance manifested in CML. Therefore, the expression of BCRP (37.5\%) in CML patients was determined. Also, the precise mechanisms of resistance to imatinib in CML patients are currently unknown, but recent data indicated that they might be due to BCRP expression. Burger et al. investigated whether imatinib is a substrate for the BCRP drug pump. They reported that overexpression of BCRP in the gastrointestinal tract might not only play a role in cellular resistance of tumor cells but also influence the gastrointestinal absorption of imatinib. ${ }^{50}$ In our study, however, no significant correlation was found between imatinib treatment and BCRP expression.

In this study it was demonstrated that chronic leukemia patients can vary in terms of expression of MDR1, LRP and BCRP genes. Analysis of these gene expressions at diagnosis of chronic leukemia may provide useful prognostic information. Such data will also help to determine the mechanisms underlying drug resistance. Further studies of these resistance gene functions and their inhibitions are needed to overcome MDR1, LRP and BCRP mediated drug resistance in chronic leukemias.

\section{Acknowledgements}

We gratefully acknowledge helps of Dr. Aykut İnan İseri about statistical analysis. This study was supported by TUBITAK (SBAG 3297, BIDEB), Turkey.

\section{REFERENCES}

1. Dalton WS. Mechanisms of drug resistance in hematologic malignancies. Semin Hematol 34: 3-8, 1997.

2. Deuchars KL, Ling V. P-glycoprotein and multidrug resistance in cancer chemotherapy. Semin Oncol 16: 156-165, 1989.

3. Gottesman MM, Pastan I. Biochemistry of multidrug resistance mediated by the multidrug transporter. Annu Rev Biochem 62: 385-427, 1993.

4. Litman T, Brangi M, Hudson E, et al. The multidrug-resistant phenotype associated with overexpression of the new ABC half-transporter, MXR (ABCG2). J Cell Sci 113: 2011-2021, 2000. 
35. Giles FJ, Kantarjian HM, Cortes J, et al. Multidrug resistance protein expression in chronic myeloid leukemia: associations and significance. Cancer 86: 805813, 1999.

36. Galimberti S, Cervetti G, Guerrini F, et al. Quantitative molecular monitoring of BCR-ABL and MDR1 transcripts in patients with chronic myeloid leukemia during Imatinib treatment. Cancer Genet Cytogenet 162: 5762, 2005.

37. Zong Y, Zhou S, Sorrentino BP. Loss of P-glycoprotein expression in hematopoietic stem cells does not improve responses to imatinib in a murine model of chronic myelogenous leukemia. Leukemia 19: 15901596, 2005.

38. Baran Y, Salas A, Senkal CE, et al. Alterations of Ceramide/Sphingosine1-Phosphate Rheostat Involved in the Regulation of Resistance to Imatinib-induced Apoptosis in K562 Human Chronic Myeloid Leukemia Cells. J Biol Chem 282: 10922-10934, 2007.

39. Borg AG, Burgess R, Green LM, et al. Overexpression of lung-resistance protein and increased pglycoprotein function in acute myeloid leukaemia cells predict a poor response to chemotherapy and reduced patient survival. Br J Haematol 103: 1083-1091, 1998.

40. List AF, Spier CS, Grogan TM, et al. Overexpression of the major vault transporter protein lung-resistance protein predicts treatment outcome in acute myeloid leukemia. Blood 87: 2464-2469, 1996.

41. Kedersha NL, Miquel MC, Bittner D, et al. Ribonucleoprotein structures are highly conserved among higher and lower eukaryotes. J Cell Biol 110: 895-901, 1990.

42. Volm M, Mattern J, Koomagi R. Expression of lung resistance-related protein $(\mathrm{LRP})$ in non-small cell lung carcinomas of smokers and non-smokers and its predictive value for doxorubicin resistance. Anticancer Drugs 8: 931-936, 1997.

43. Uozaki $\mathrm{H}$, Horiuchi $\mathrm{H}$, Ishida $\mathrm{T}$, et al. Overexpression of resistance-related proteins (metallothioneins, glutathione-S-transferase PI, heat shock protein 27 and lung resistance-related protein) in osteosarcoma: relationship with poor prognosis. Cancer 79: 23362344, 1997.

44. Dingemans AM, van Ark-Otte J, van der Valk $P$, et al. Expression of the human major vault protein LRP in human lung cancer samples and normal lung tissues. Ann Oncol 7: 625-630, 1996.
45. Schadendorf D, Makki A, Stahr C, et al. Membrane transport proteins associated with drug resistance expressed in human melanoma. Am J Pathol 147: 1545-1552, 1995.

46. Ramani $P$, Dewchand $H$. Expression of MDR1/Pglycoprotein and p110 in neuroblastoma. J Pathol 175: 13-22, 1995.

47. Consoli U, Santonocito A, Stagno F, et al. Multidrug resistance mechanisms in chronic lymphocytic leukaemia. Br J Haematol 116: 774-780, 2002.

48. Carter A, Dann EJ, Katz T, et al. Cells from chronic myelogenous leukaemia patients at presentation exhibit multidrug resistance not mediated by either MDR1 or MRP1. Br J Haematol 114: 581-590, 2001.

49. Quiney C, Billard C, Faussat AM, et al. Hyperforin inhibits P-gp and BCRP activities in chronic lymphocytic leukaemia cells and myeloid cells. Leuk Lymphoma 48: 1587-1599, 2007.

50. Burger $H$, van Tol $H$, Boersma $A W$, et al. Imatinib mesylate (STI571) is a substrate for the breast cancer resistance protein (BCRP)/ABCG2 drug pump. Blood 104: 2940-2942, 2004.

\section{Correspondence}

Prof. Dr. Ufuk GÜNDÜZ

Ortadoğu Teknik Üniversitesi

Biyolojik Bilimler Bölümü

06531 Ankara / TURKEY

Tel: (+90.312) 2105184

Fax: (+90.312) 2107976

e-mail: ufukg@metu.edu.tr 